\title{
The Simultaneous Economic Impact of the Corona Virus and the Reduction of Oil Prices on OPEC Organization
}

\author{
Mosaad Mohamed Elgayish \\ Economics Department, Faculty of Politics \&Economics, Beni-Suef University, Beni-Suef, Egypt
}

Email address:

mosaad2000@eps.bsu.edu.eg

\section{To cite this article:}

Mosaad Mohamed Elgayish. The Simultaneous Economic Impact of the Corona Virus and the Reduction of Oil Prices on OPEC Organization. International Journal of Economy, Energy and Environment. Vol. 6, No. 1, 2021, pp. 1-10. doi: 10.11648/j.ijeee.20210601.11

Received: December 24, 2020; Accepted: January 6, 2021; Published: January 18, 2021

\begin{abstract}
The world's impact coincided with two major events at the same time that had a major impact on the global economy without exception in the beginning of 2020, as there was a very large drop in oil prices at the level of the world, as this coincided with the emergence of the Corona virus, which affected the economy of all countries of the world without exception, and so it was the research problem is summarized in reaching the extent of the impact of the coincidence of a decrease in global oil prices with the existence of the Corona crisis on OPEC organization, and therefore the multiple regression model was relied upon, depending on the World Bank data, and the research concluded that $78.1 \%$ of the change in $Y$ is due to The change in $X 4$ and $X 3$ and $21.9 \%$ of the changes due to other factors were not taken into account. It is noticed that $54.6 \%$ of the change in $\mathrm{Y}$ is due to the change in oil price $X 3$ and $23.5 \%$ of the change in $Y$ is due to the change in $X 4$, and the research also found that it was the Corona pandemic Clear effects were reflected in the image of reducing oil demand as a result of the precautionary measures taken by the countries of the world to confront the Corona pandemic, especially with the prevention of air traffic, as well as the reduction of travel by land. Based on this, the research recommends that OPEC organization should prepare for the near future by developing flexible strategies and scenarios that take into account the sharp price fluctuations of oil, not fully relying on oil as a source of public revenues for some OPEC countries, and working on finding auxiliary factors as a source of income in addition to oil. Besides activating the role of a management for disease crises and pandemics, take their consequences into consideration, and follow scientific methods in facing their economic consequences.
\end{abstract}

Keywords: The Economic Impact, Simultaneous, Corona Virus, Oil Prices, OPEC Organization

\section{Introduction}

OPEC $^{1}$ was established in 1960 in Baghdad. Five important countries in oil production have established that organization, namely Iraq, Saudi Arabia, Kuwait, Venezuela and Iran, and its headquarters are in Vienna. Then Qatar joined in 1961 and then left at the end of 2018. It also joined Indonesia in 1962 and then left 2008, as Libya joined in 1961, and the UAE in 1967 (it joined in the name (Abu Dhabi) and then changed its name to the Emirates in 1974), then it joined Algeria in 1969, Nigeria in 1971, Ecuador in 1973 and Gabon, which started as an associate member in the year 1973 and then became a full member in 1975. The OPEC member states in this organization own $40 \%$ of global output

1 Organization of Petroleum Exporting Countries. and $70 \%$ of world oil reserves. OPEC has huge oil potential in terms of reserves and production. These quantities make it a large economic oil bloc that can control the global oil market. Approval of a new member country requires the approval of three quarters of the current members of OPEC, including all five founders. [11]

The price of crude oil fluctuates up and down affected by many economic determinants of supply and demand factors and their flexibility, as well as the global growth rate, inflation and unemployment rates, as well as political determinants and factors, so we find, for example, that the global average price of crude oil in US dollars according to World Bank data in 1990 was approximately \$22.26 per barrel, exceeding \$ 109 in 2012. [20]

If the traditional sources of energy (coal, petroleum, natural gas) are at risk of depletion, in addition to causing 
environmental pollution and climate change issues, renewable energy sources are devoid of these risks and it becomes possible to overcome the difficulties and challenges facing the exploitation of renewable energy sources. The European Union achieved the highest growth rate in wind energy production, which was $19 \%$ in 2006. [8] In addition,

The emergence of the Coronavirus also had a noticeable impact in 2020 on the global economy, and there is no doubt that the coincidence of the remarkable decline in crude oil prices and the reflection of the observed effects of the Corona virus on the global economy had a marked impact on OPEC. [20]

Moreover at the beginning of 1981, wind energy became a rapidly growing field after the efforts made during the 1970 s in research and development on a wealth of recent studies that proved that wind energy is a practical source of electricity. The need to find an alternative to petroleum became urgent in the United States as a result of the fuel shock in the seventies, as the United Kingdom is considered one of the richest wind energy systems in Europe, and the growth of the wind energy industry in China began with the issuance of a comprehensive renewable energy law in 2005. [6]

\section{Research Problem}

The occurrence of the sharp decline in crude oil prices in the first half of 2020 with the emergence of the Corona virus at the same time had a clear impact on the global economy without exception, as there has been a very large drop in oil prices worldwide as a result of the increase in the supply of American shale oil with the increase of Russia's share And the OPEC countries, at the same time, resulted in a significant drop in crude oil prices worldwide, just as this coincided with the emergence of a health catastrophe that affected all countries of the world without exception, Global oil demand in such a way that made a barrel of crude oil reach its lowest levels ever, and therefore the problem of research lies in reaching the extent of the impact of the coincidence of a decrease in global oil prices with the existence of the Corona crisis on OPEC organization. The importance of the research stems from the fact that it looks at the coincidence of two major events at the same time that plunged the world into a state of apparent economic recession, In addition to the importance of this issue in particular to OPEC countries, especially those that depend on oil as a main source of national income, with the relative importance of the remaining sources of income being low compared to the income flowing from oil.

\section{Previous Studies}

The study of Abd al-Sattar Moussa found that $75 \%$ of oil reserves are in OPEC, $61.9 \%$ of those reserves are in the Middle East region and the rest is distributed to the rest of the world, and that the world countries except OPEC suffers from a deficiency to face its consumption of oil, the study also indicated that the continuous fluctuation in OPEC's share of international production for the period from 1970 to 2005 reflects the behavior of OPEC in production as a model of oligopoly, and the production of countries outside OPEC was characterized by continuous increase and constant rates consistent with the growth of its reserves, unlike OPEC production. In addition, all indications indicate that the future of crude oil is in the reserves of the Middle East, because reserves outside OPEC are declining, especially in the North Sea region. [1]

another study by Nashwi Mustafa, it was shown that linking oil prices to a basket of currencies instead of the US dollar will reduce the fluctuation of oil prices due to fluctuations in global exchange rates, and it is also important to find alternatives to oil because it is a depleted resource and work to encourage investments in the field of alternative energy, which will affect the demand for oil, which will be reflected in oil prices. [10]

While the study of the Arab Center for Research and Policy Studies, found that the direct effects of the drop in oil prices center on the decrease in the value of oil export revenues that feed both the current account, the general budget and the official reserves of these countries. 2014, compared to 2013, has cast a shadow over the macroeconomic variables of the Middle East oil-exporting countries, but its effects are limited and uneven between countries. [18]

Another study by Geoffrey Heal and Karoline Hallmeyer concluded that low oil prices may help slow the growth of the renewable energy market, and a small portion of oil is used in power generation in the United States and the world, and the study confirms that oil will not compete with renewable energy sources in generating Electric energy, and for oil-fired power plants to be able to compete with renewable energy, oil prices must drop to low levels - around $\$ 15$ a barrel according to the study, a price level at which most oil producers lose their money. [7]

As the study of the Arab Center for Research and Policy Studies found that the result of applying the strategy to preserve market share during two years (2014-2016) was negative and was more harmful to OPEC countries, as the organization's oil revenues fell sharply more than at the level of oil production confined to The United States of America with an unclear or intangible effect of the decrease in the price of oil on its share in the world market. It was also found that in light of the low price elasticity of demand, the relative decrease in the quantity demanded of oil will be less than the relative increase in prices. [19]

While the study conducted by AnikaLabiba Islam \& Ana Espinola - Arredondo showed how the increased use of renewable energy in power generation affected the strategies of the oil-exporting countries and the structure of the oil market. The focus was on two strategies for OPEC countries, the first strategy is to increase the share of oil supplied before OPEC, which reduces the price of oil, while the second strategy is to allow competitors with high costs to remain in the market. The conclusion of the study was that when the 
inefficient non-OPEC members are more attractive to OPEC when they are ineffective in producing renewable energy, consumers look at both. The two commodities are homogeneous products, in addition to the pressure strategy stimulating more renewable energy production when the cost is low, and finally if non-OPEC countries can influence the price, then the pressure strategy arises under less demanding conditions when renewable energy is available. [2]

As a study conducted by Troster, Victor and Shahbaz, Muhammed and Uddinm, Gazi Salah, found a causal relationship between renewable energy consumption, oil prices and economic activity in America from June 1989 to July 2016, and the study found that there is a two-way causation between changes in renewable energy consumption and economic growth at the lowest distribution quantities. The study also found that negative shocks in oil prices affect the consumption of renewable energy resources. The study also recommended the need to support policies that help renewable energy companies only during periods of negative shocks to oil prices. [20]

As Pinar Deniz also presented a study that concluded that the rise in oil prices may lead to a reduction in demand for it and the trend towards generating energy from renewable energy, which leads to a shock to the oil-exporting countries, and that the rise in oil prices positively affected oil-importing countries while negatively affecting On the oil-exporting countries, as the study also showed that the oil-exporting countries have no intention of switching to reliance on renewable energy because the conversion to renewable energy is very costly even if the oil reserves in these countries dwindle. [16]

Finally, OPEC Bulletin 2020 confirmed on the report of the World Economic Forum 2020 that emphasized the seriousness of the economic and social impact of disasters and health diseases that reach the limit of a pandemic such as Covid 19. The report recommended the need to increase the role of the private sector by increasing partnership with the public sector and the need to trust the private sector to reduce the impact of economic shocks on the global economy, especially at a time of economic pandemics. [12], while the researcher tries to measure the extent to which OPEC is affected by the decline in crude oil prices in conjunction with the impact of the Corona virus.

\section{Research Hypothesis and Methodology}

The research assumes that the coincidence of a decrease in global oil prices and the occurrence of the Corona crisis had a clear impact on oil revenues for OPEC organization, as at a time when many oil-producing countries struggled to increase the supply of it, the world witnessed the Corona virus crisis, which It doubled the negative effects on OPEC's revenues, and the decline in growth rates in the world's economies without exception exacerbated the impact of that crisis, which helped reduce global demand for oil, which puts petroleum countries that depend on oil as a main source of income in a dilemma. In addition, America declined in demand for oil because it relied heavily on US shale oil, which made it enter the export market after it was an oil importer. Therefore, the multiple regression model has been relied on to reach the extent of the impact of the decline in global oil prices on the revenues of OPEC countries according to the data of the World Bank, where it was assumed that the variable $Y$, which is the dependent variable in the equation, expresses the revenues of $O P E C$ as a percentage of the gross domestic product, as was expressed For the independent variables represented in each of ( $X 1$ the global growth rate as an expression of the evolution of oil demand, $X 2$ the share of $O P E C$ countries in global production, $X 3$ the global average price of oil in US dollars, $X 4$ the contribution of renewable energy in power generation in the world, $X 5$ oil sales In barrels, $X 6$, global inflation rate, $X 7$ global unemployment rate, and given that all the variables $y, X 1, X 2, X 3, X 4, x 5, x 6, x 7$ were entered on EVIEWS and the Unit Root Test Augmented Dickey-Fuller Test Equation and Phillips were performed-Perron test statistic on it, all were stable at level.

\section{OPEC Organization}

One of the most important reasons for the existence of OPEC was the conglomeration of international companies (the global cartel or the global government for oil), and its isolation of the world's wealth and developing countries, and perhaps this conglomerate is one of the most important reasons for its control over the global oil industry. Moreover Mexico nationalized its oil in 1938, then Iran nationalized its oil in 1951, but the monopolistic companies used their political and economic influence and thwarted the two attempts and considered them the most dangerous revolutions against its oil interests. Also, the oil-producing countries feel injustice regarding the privileges, influence, and control of their national capabilities of the monopolistic companies and the colonial powers. The companies were forced to use various weapons from boycotting the nationalized oil exports to exerting political and economic pressure on the national forces in these two countries and on other countries to force them to compensate for the shortage in oil supplied. The national uprisings also had many goals, the most prominent of which was the liberation of their wealth and resources from the grip of the colonial powers, whose main reasons for their strength were their cooperation, coordination, conglomeration and support for their monopolistic companies This was at a time when the emergence of liberal leaders and thinkers focused on the importance of political and economic independence, and focused on the role of oil wealth in this direction, as well as the emergence of two competing international poles after World War II, as well as the emergence of the Non-Aligned Movement. [3]

\subsection{OPEC Objectives}

OPEC aimed to coordinate and unify oil policies among member states in order to secure fair and stable prices for oil producers, economic efficiency and regular supplies of oil to 
consuming countries. And work to keep the price of oil exploited by the international oil cartel (the multinational companies) outside its borders at a high level. In addition to the organization's work to ensure equality among its members, the organization also works to unify the efforts of oil-producing countries to extract a greater share of the profits resulting from the exploitation of their own wealth. The organization also works to organize and strengthen the position of oil-exporting countries in its relationship with the concessionary companies. [5]

\subsection{Conditions for Joining OPEC}

It is permissible for any country to join the membership of the organization if several conditions are met, including that the state achieves a large surplus of oil allocated for export, after covering its domestic needs, and the oil interests of the member state must be similar to a large extent with the conditions of the country that found the organization, in addition to the necessity three-quarters of the organization's members agree to accept the new member, including the five founding states of the organization, meaning that the opposition of any founding state prevents the joining of the new member. [5]

\subsection{OPEC Organizational Structure}

\subsubsection{Ministerial Conference}

The ministerial conference of the organization is the supreme authority and works according to the principles of consensus. It is responsible for setting and formulating its general policy. It also meets twice a year at the organization's permanent headquarters in order to coordinate and unify oil policies, and the conference elects a president who will remain until the new session is held, also the policy approval, Moreover overseeing the implementation of the general policy of the organization and finally approve the budget. [5]

\subsubsection{Board of Governors}

The Board of Governors consists of a representative from each member state with the approval of the conference, and this membership continues for a period of two years. The Council holds two regular meetings annually, moreover, it may hold extraordinary meetings when necessary at the request of the Chairman of the Board and the Secretary General, or at the request of two-thirds of the total of governors, the Board supervises the direction of management, the implementation of the decisions of the conference and submit recommendations to the conference (each within its competence) and take decisions. [4]

\subsubsection{The General Secretariat}

The General Secretariat was established in 1961 and it is responsible for implementing the activities of the organization, works according to the instructions of the Board of Governors, it consists of the Secretary-General, the Deputy Director General, the Research Department, the Personnel and Administrative Affairs Department, the Media
Department, the Secretary General's Office and the Legal Affairs Unit. It is worth noting that OPEC In 1976, it took the initiative to establish OPEC Fund for International Development to provide aid to developing countries. [5]

\subsubsection{Ministerial Monitoring Committee}

It was established in 1993, its mission is to control production quotas and exports of member states, as it consists of three ministers and the Secretary General. Extraordinary sessions may be held in the presence of three quarters of all members, and decisions are taken unanimously and do not become effective until thirty days after the date of the meeting. [4]

\subsubsection{OPEC Advisory Board}

It is a consultative organization that meets at least once a year to discuss some points, including improving contractual conditions and the need to consult on the issue of price change. It is also concerned with increasing the capacity of oil refineries in the producing countries, and is working on establishing national oil companies, as well as an understanding regarding maintenance, production and exploration of oil resources. It was agreed to draft a charter signed at the end of the meetings. This document was known as the "Maadi Agreement," which was the first initiative to establish OPEC, and it was in Cairo in April 1959. [4]

\subsection{Reserves - Production - Exports}

\subsubsection{Reserves}

OPEC has enormous oil potential in terms of reserves and production, and these quantities make it a large economic oil conglomerate that can control the global oil market. OPEC's reserves reached about 903 billion barrels in 2005, as it constituted the equivalent of $78.3 \%$ of global reserves Moreover; more than $88 \%$ of them are in five countries (Saudi Arabia, Iran, Iraq, Kuwait, the Emirates, and Venezuela). OPEC reserves remained stable during the period from 2000 to 2011 , as they ranked first in relation to the rest of the world. In 2012, the OPEC countries 'proven crude oil reserves reached $1,200,830$ billion barrels, which is $81 \%$ of the world's proven oil reserves estimated at 1,478,211 billion barrels, and the largest part of the OPEC countries' oil reserves are located in the Middle East, accounting for $66 \%$ of the total OPEC. In 2018, OPEC reserves reached $79.4 \%$ of global reserves. [11]

\subsubsection{Production}

Oil prices declined after 1980 with the beginning of the Iraq-Iran war, as OPEC began to reduce production quotas to prevent the price collapse, and therefore its contribution to global production decreased to $29 \%$ in $1985,36 \%$ in 1990 , and $37 \%$ in 1995 . Then its contribution increased to about $37 \%$ in 2000 , then $41 \%$ in 2005 , then increased to 45.70 in 2012 , then decreased in 2018 to $42 \%$ of global production. [11]

\subsubsection{Exports}

The volume of OPEC countries 'crude oil exports in 2012 reached $25,281.4$ million barrels per day, or $62.49 \%$ of global 
exports estimated at 40.452 million barrels per day. The value of oil exports in 2012 to OPEC countries was estimated at $1,688,229$ billion US dollars and in 2020, about $\$ 400$ billion.

\section{OPEC share of world crude oil reserves, 2018}

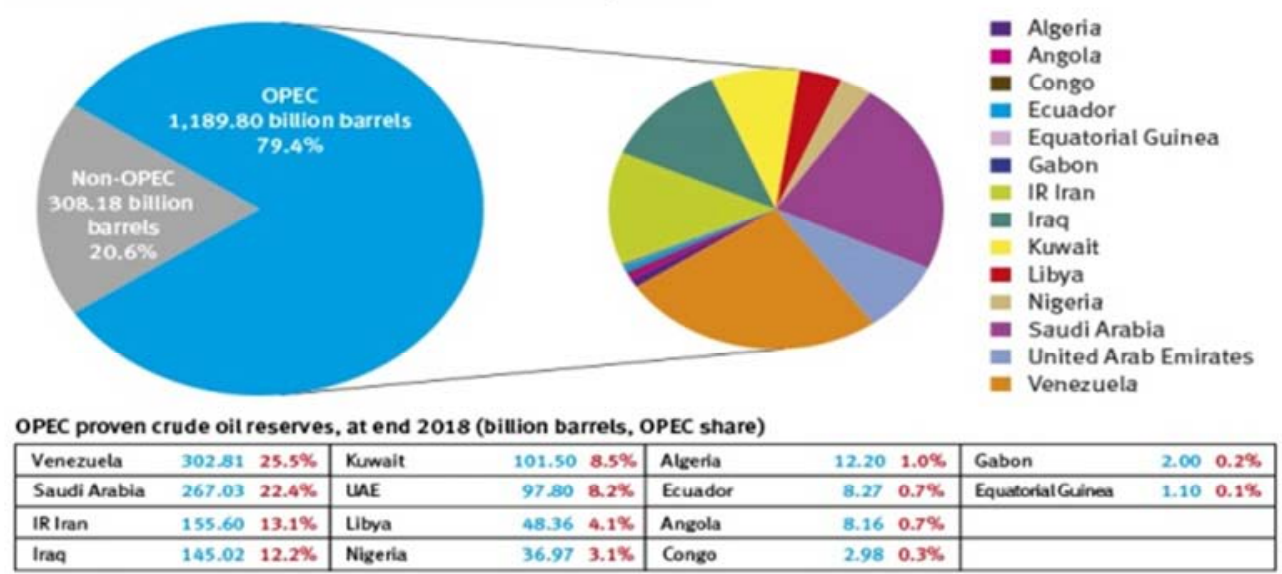

Sourcer OPEC Annual Statistical Bulletin 2019.

Figure 1. www.opec.org/opec_web/en/data_graphs/330.htm [13].

The diagram shows the share of OPEC countries in crude oil reserves, as is the share of each OPEC countries separately from oil reserves

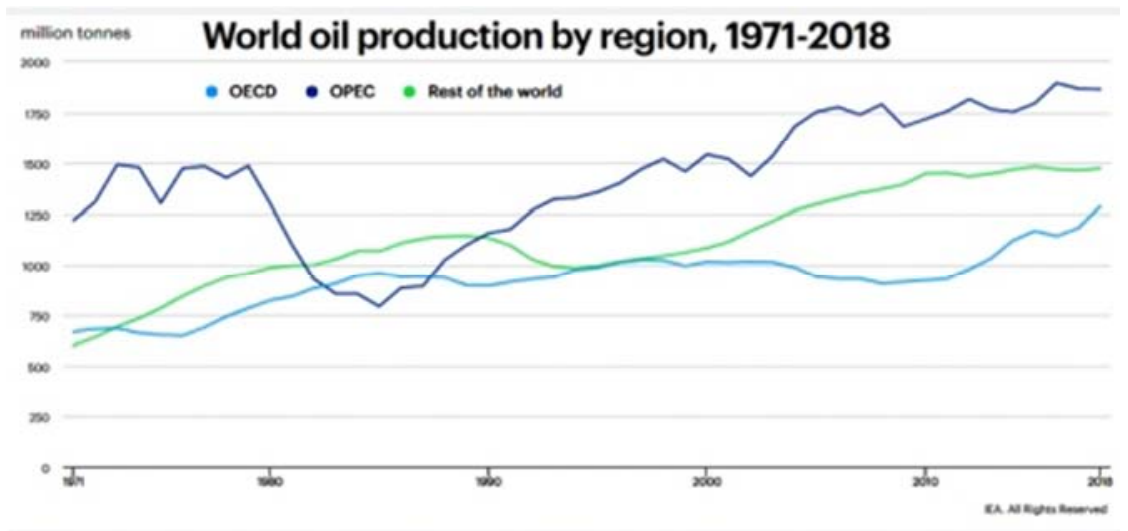

Figure 2. https://energypost.eu [23].

Figure 2 shows World oil production by region, and it is clear that OPEC organization production increased over the last 10 years

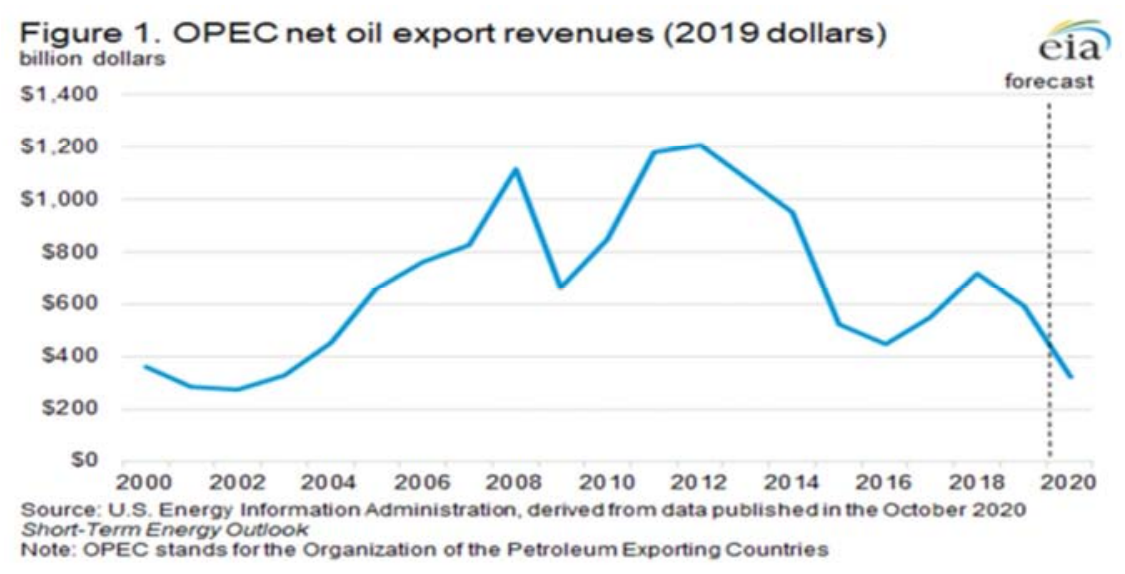

Figure 3. Oil \& Gas Journal (ogj.com [15].

This figure shows how OPEC net oil exports revenues fluctuated during the last ten years. 


\section{An Analysis of the Factors Affecting the Revenues of OPEC}

\subsection{OPEC Revenue Development}

The revenues of OPEC countries represented about $23 \%$ of the gross domestic product of the countries of the organization in 1990, then the percentage decreased in 1991 to only $18 \%$, then the percentage decreased to $15 \%$ in 1995 , while this percentage increased to $25 \%$ in 2004 and then to $31 \%$ In 2005 , then it decreased to its lowest level in 2016 to $13 \%$, then $18 \%$ in $2017-2018^{2}$. [14]

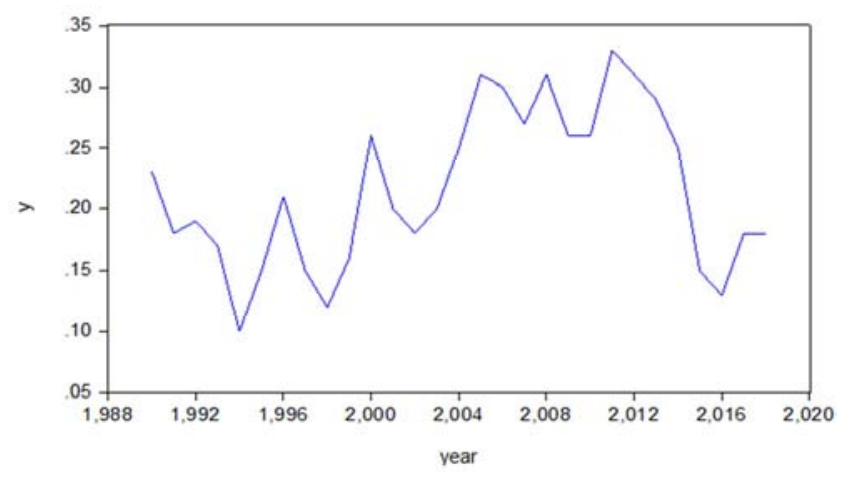

Figure 4. The development of the revenues of the OPEC-Y petroleum exporting countries as a percentage of the gross domestic product of the OPEC countries, based on data from the World Bank [14].

It is noticed that $54.6 \%$ of the change in $Y$ is due to the change in $X 3,23.5 \%$ of the change in $Y$ is due to the change in $x 4$, and $21.9 \%$ of the changes are due to other factors not taken into account, and the Model as a whole is significant and all the variables included in the model are significant, the effect of $X 3$ is positive It is in agreement with the prejudgment of the variable inclination signal, the $X 4$ effect is negative, and it is in agreement with the pre-judgment of the variable inclination signal, and the model does not suffer from the self-correlation problem according to the BreuschGodfrey Serial Correlation LM Test, nor does it mean from the problem of variability instability according to Heteroskedasticity Test: White and the residues follow the normal distribution according to the HISTOGRAMNORMALITY TEST and no linear duplication problem.

$$
\text { Y } 0.391756+0.002075 \text { X 3-0.0161 X4 }
$$

This table shows that $78.1 \%$ of the change in $\mathrm{Y}$ is due to The change in $\mathrm{X} 4$ and $\mathrm{X} 3$ and $21.9 \%$ of the changes due to other factors were not taken into account.

Moreover, the sharp decline in oil demand is linked to the sharp decline in economic activity around the world as a result of precautionary measures. The study of Rabah Arezki, Hangwen, 2020 has reached that a 10\% decrease in oil

2 It was taken into account that the country of Indonesia was a member of OPEC until 2008, and the state of Gabon was a member until 1994, global demand for oil and renewable energy in power generation. consumption in 2019 or about 10 million barrels per day is a result of the decrease in air and land travel. [17] The LopezCordova, Ernesto. 2020 study concluded that net oil exports or oil revenues to OPEC average decline in the global oil price and The impact of decreased oil prices and the Corona pandemic is not only limited to exporters but also indirectly affected by oil-importing countries, through a decrease in foreign direct investment and remittances from workers abroad and tourism in addition to the decrease in grants provided by oil-exporting countries to other countries. [9]

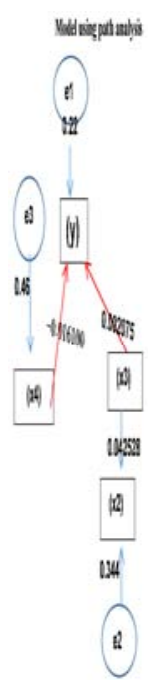

Figure 5. Summarize results of econometrics model by using path analysis.

\subsection{Global Growth Rate X1}

The global growth rate witnessed a remarkable decline in 1991 , as it recorded $1.48 \%$ in 1991, after it was 2.92 in 1990, then it recorded a remarkable increase in 1997, which recorded $3.68 \%$, then decreased significantly in 2001, reaching $1.95 \%$, then it recorded a clear decline Negative in 2009 , where it reached $-1.68 \%$, then increased to 4.30 in 2011 , before declining again to $2.97 \%$ in 2018 .

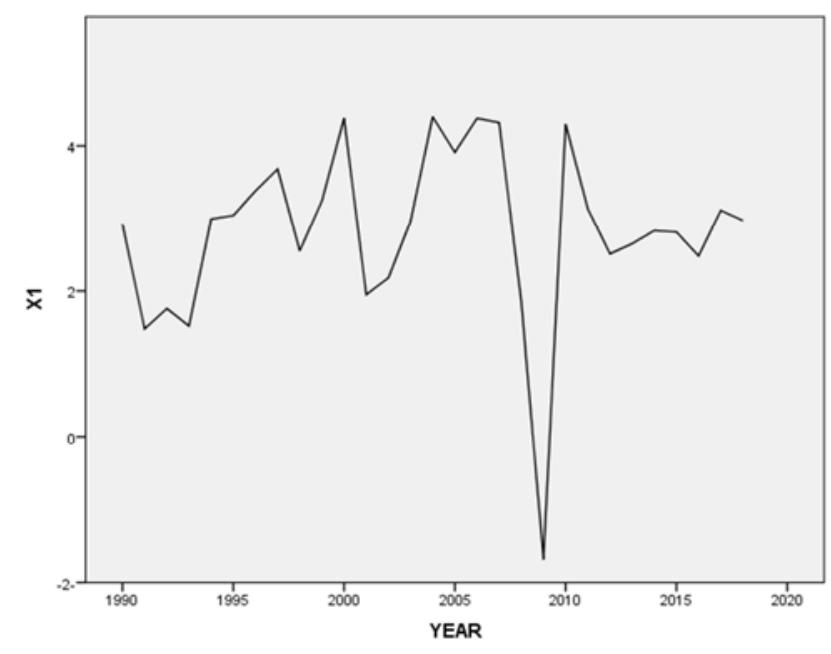

Figure 6. Global growth rate based on data from the World Bank [14]. 
Table 1. The change in $X 4$ and $X 3$.

\begin{tabular}{lllll}
\hline Model Summary & & & & \\
\hline Model & R & R Square & Adjusted R Square & Std. Error of the Estimate \\
\hline 1 & $.739^{\mathrm{a}}$ & .546 & .529 & .04457 \\
2 & $.884^{\mathrm{b}}$ & .781 & .764 & .03154 \\
\hline
\end{tabular}

a. Predictors: (Constant), X3

b. Predictors: (Constant), X3, X4

\subsection{OPEC's Share of Global Production X2}

The share of OPEC in global production recorded $37.30 \%$ in 1990 , then increased to 42.10 in 2000 , after that, decreased in 2002 to $40 \%$, then recorded a remarkable increase in 2006 , reaching 44.10 , and then decreased again in 2016 to $41 \%$, finally reached to $42 \%$ in 2018 .

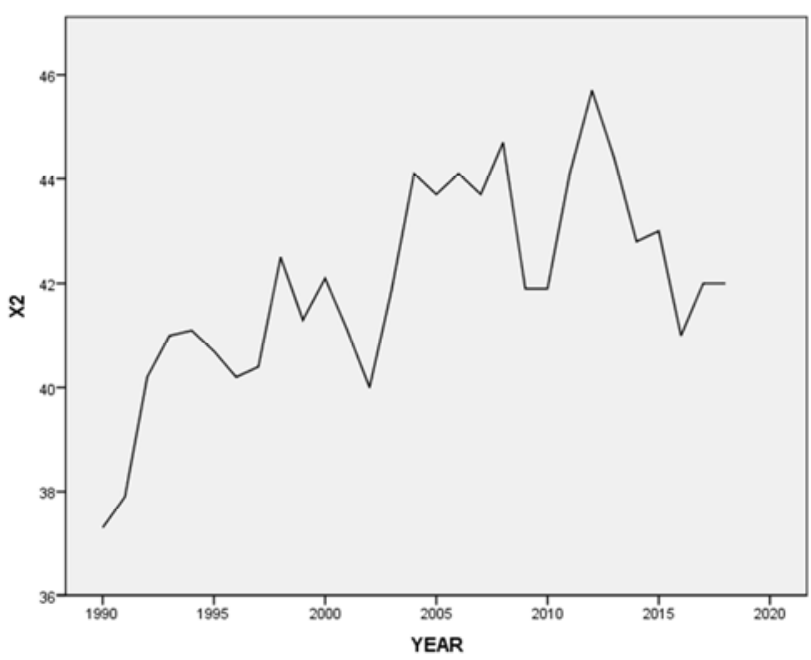

Figure 7. OPEC's share of global production X2 based on data from the World Bank [14].

\subsection{World Average Price of Oil a Barrel in Dollars X3}

While the average world price of a barrel of oil fluctuated between $\$ 22.26$ in 1990 , then decreased to \$ 18.62 in 1991 , then increased in 1996 to $\$ 20.29$, then jumped in 2004 to $\$ 36.05$, then jumped in 2010 to $\$ 77.38$, While there were successive jumps in the years 2011, where the price of a barrel reached \$ 107.46, then 109.45 in 2012, then 105.87 in 2013 , before declining again in 2018 to 69.78 .

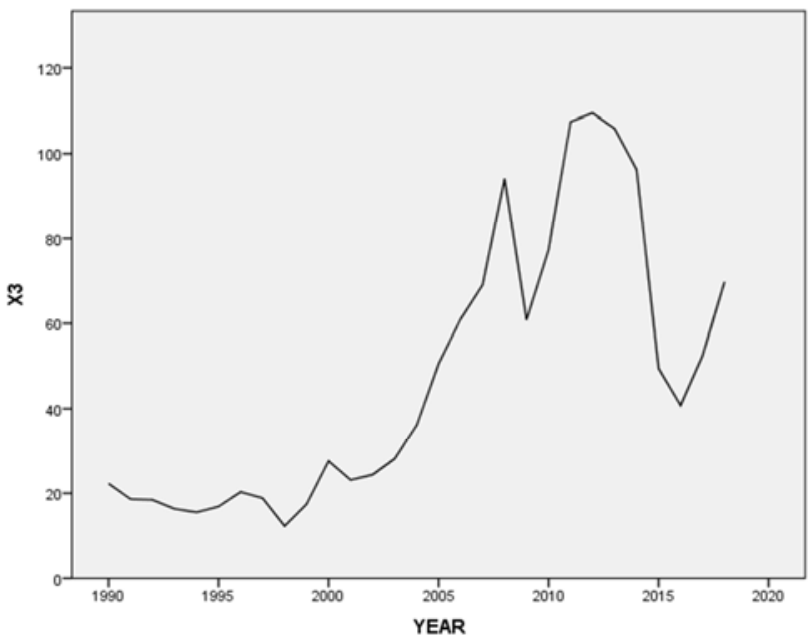

Figure 8. Global average oil prices - dollars, depending on data, https://www.statista.com/statistics [21].

\section{Crude oil prices in 2020}

Both Brent crude and West Texas Intermediate prices have been under pressure since late January as concerns over the coronavirus emerged

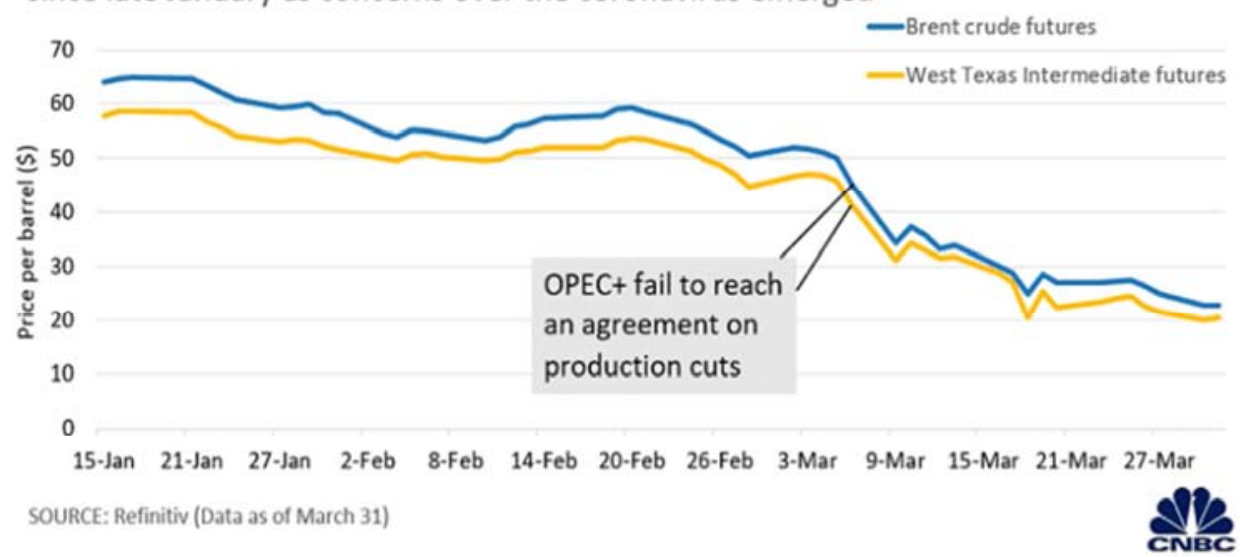

Figure 9. www.cnbc.com [24]. 
The figure shows how crude oil prices fall in 2020.

Table 2. Summarize econometrics results.

\begin{tabular}{|c|c|c|c|c|c|c|c|c|c|}
\hline \multicolumn{10}{|c|}{ Correlations } \\
\hline & & $\mathbf{Y}$ & $\mathrm{X} 4$ & $\mathbf{X 1}$ & $\mathrm{X3}$ & $\mathrm{X} 2$ & $\mathrm{X5}$ & X6 & $\mathrm{X} 7$ \\
\hline \multirow{3}{*}{ Y } & Pearson Correlation & 1 & -.045 & .200 & $.739^{* *}$ & $.602^{* *}$ & $-.398-^{*}$ & -.169 & .130 \\
\hline & Sig. (2-tailed) & & .815 & .297 & .000 & .001 & .032 & .381 & .501 \\
\hline & $\mathrm{N}$ & 29 & 29 & 29 & 29 & 29 & 29 & 29 & 29 \\
\hline \multirow{3}{*}{$\mathrm{X} 4$} & Pearson Correlation & $-.045-$ & 1 & .013 & $.505^{* *}$ & .280 & $-.736-^{* *}$ & $-.563-^{* *}$ & .068 \\
\hline & Sig. (2-tailed) & .815 & & .946 & .005 & .142 & .000 & .001 & .724 \\
\hline & $\mathrm{N}$ & 29 & 29 & 29 & 29 & 29 & 29 & 29 & 29 \\
\hline \multirow{3}{*}{$\mathrm{X} 1$} & Pearson Correlation & .200 & .013 & 1 & .057 & .273 & $-.137-$ & $-.184-$ & .212 \\
\hline & Sig. (2-tailed) & .297 & .946 & & .767 & .151 & .477 & .338 & .271 \\
\hline & $\mathrm{N}$ & 29 & 29 & 29 & 29 & 29 & 29 & 29 & 29 \\
\hline \multirow{3}{*}{$\mathrm{X} 3$} & Pearson Correlation & $.739^{* *}$ & $.505^{* *}$ & .057 & 1 & $.728^{* *}$ & $-.745-^{* *}$ & $-.371-^{*}$ & .163 \\
\hline & Sig. (2-tailed) & .000 & .005 & .767 & & .000 & .000 & .047 & .398 \\
\hline & $\mathrm{N}$ & 29 & 29 & 29 & 29 & 29 & 29 & 29 & 29 \\
\hline \multirow{3}{*}{$\mathrm{X} 2$} & Pearson Correlation & $.602^{* *}$ & .280 & .273 & $.728^{* *}$ & 1 & $-.677_{-}^{* *}$ & $-.404-^{*}$ & $.483^{* *}$ \\
\hline & Sig. (2-tailed) & .001 & .142 & .151 & .000 & & .000 & .030 & .008 \\
\hline & $\mathrm{N}$ & 29 & 29 & 29 & 29 & 29 & 29 & 29 & 29 \\
\hline \multirow{3}{*}{$\mathrm{X} 5$} & Pearson Correlation & $-.398-^{*}$ & $-.736-^{* *}$ & $-.137-$ & $-.745-^{* *}$ & $-.677_{-}^{* *}$ & 1 & $.764^{* *}$ & $-.497-^{* *}$ \\
\hline & Sig. (2-tailed) & .032 & .000 & .477 & .000 & .000 & & .000 & .006 \\
\hline & $\mathrm{N}$ & 29 & 29 & 29 & 29 & 29 & 29 & 29 & 29 \\
\hline \multirow{3}{*}{$\mathrm{X} 6$} & Pearson Correlation & $-.169-$ & $-.563-^{* *}$ & $-.184-$ & $-.371-^{*}$ & $-.404-^{*}$ & $.764^{* *}$ & 1 & $-.637-^{* *}$ \\
\hline & Sig. (2-tailed) & .381 & .001 & .338 & .047 & .030 & .000 & & .000 \\
\hline & $\mathrm{N}$ & 29 & 29 & 29 & 29 & 29 & 29 & 29 & 29 \\
\hline \multirow{3}{*}{$\mathrm{X} 7$} & Pearson Correlation & .130 & .068 & .212 & .163 & $.483^{* *}$ & $-.497_{-}^{* *}$ & $-.637_{-}^{* *}$ & 1 \\
\hline & Sig. (2-tailed) & .501 & .724 & .271 & .398 & .008 & .006 & .000 & \\
\hline & $\mathrm{N}$ & 29 & 29 & 29 & 29 & 29 & 29 & 29 & 29 \\
\hline
\end{tabular}

**. Correlation is significant at the 0.01 level (2-tailed).

*. Correlation is significant at the 0.05 level (2-tailed).

\subsection{Renewable Energy Contribution $X 4$}

The international reliance on renewable energy has increased significantly in recent years, as it has recorded clear jumps from 2005 to 2019 , as shown in the following figure.

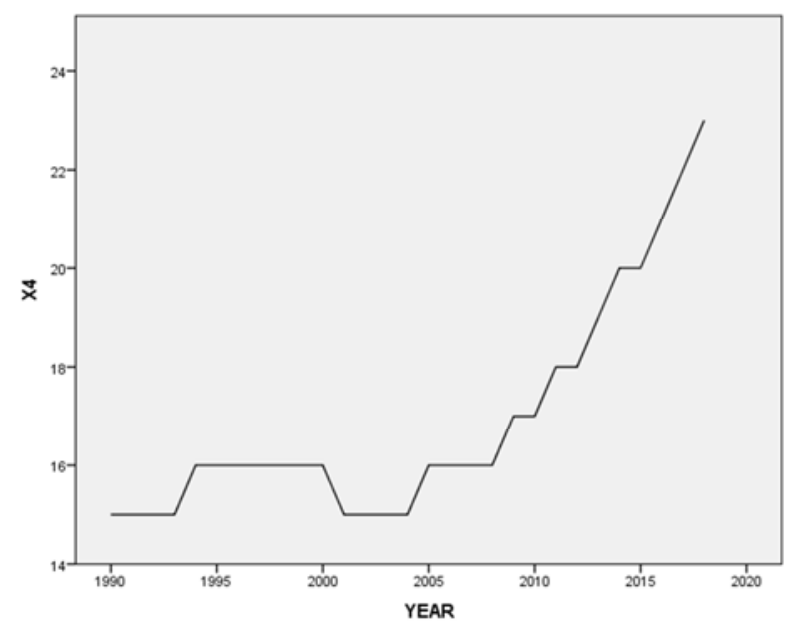

Figure 10. Contribution of renewable energy to energy generation is\% in the world - according to IEA data ${ }^{3}[22]$.

3 International Energy Agency

\subsection{Oil Sales in Barrels X5}

OPEC countries' sales ranged from 8.75 billion barrels per year of crude oil in 1990 to 8.30 billion in 1991, then to 9.20 in 2000 , then to 10.09 in 2004 , and then sales decreased in 2009 to 8.39 . Then OPEC sales increased in 2011 to 10 billion barrels, then 10.25 in 2012 , and then OPEC sales ranged from 2013 to 2016 to less than 10 billion barrels. While sales increased in 2017 to 10.89 billion barrels, we find that sales decreased in 2018 to 8.24 billion barrels.

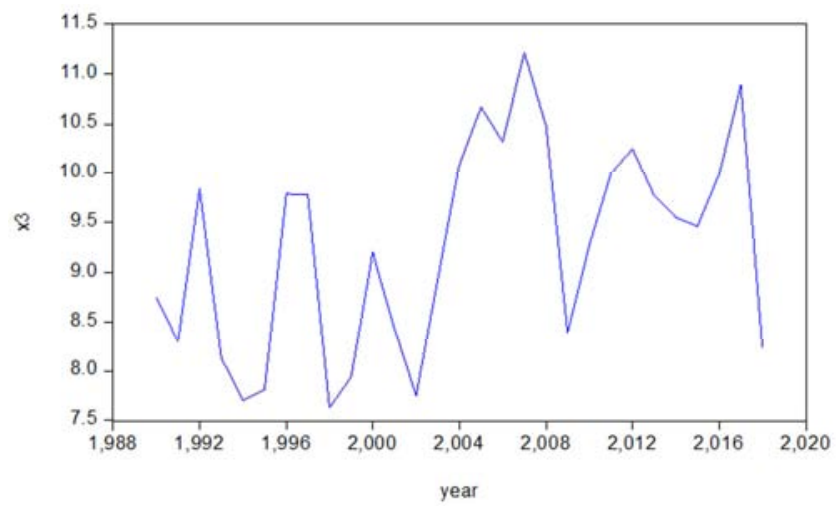

Figure 11. OPEC sales of crude oil based on data from the World Bank [14]. 


\subsection{Global Inflation Rate X6}

The global inflation rate recorded a remarkable decline from 1995 to 2000 before registering an increase again in the period from 2005 to 2008 and then reached low rates after that until 2018.

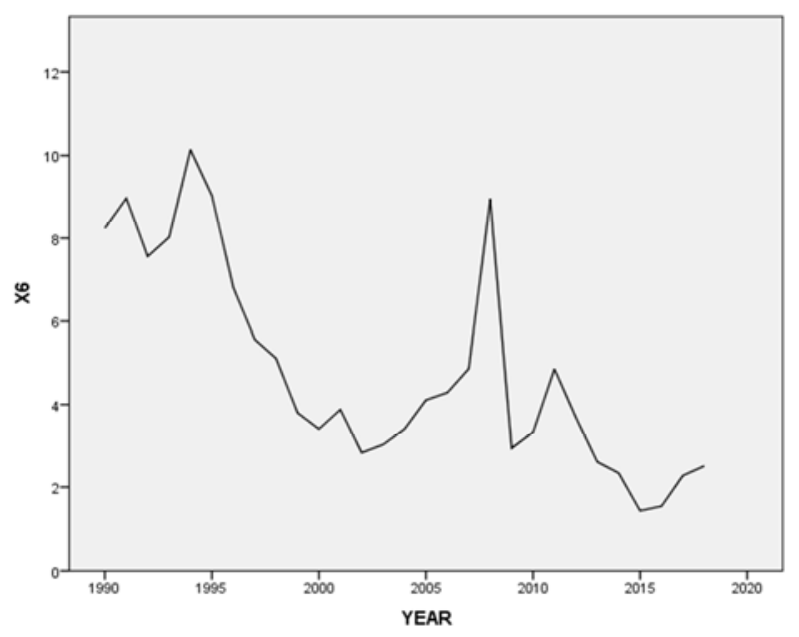

Figure 12. Global inflation rate, based on data from the World Bank [14].

\subsection{Global Unemployment Rate X7}

The period from 1990 to 2004 witnessed a clear increase in the global unemployment rate, and then it decreased again from 2005 to 2007, before it rose again, and then decreased in the period from 2011 to 2018 .

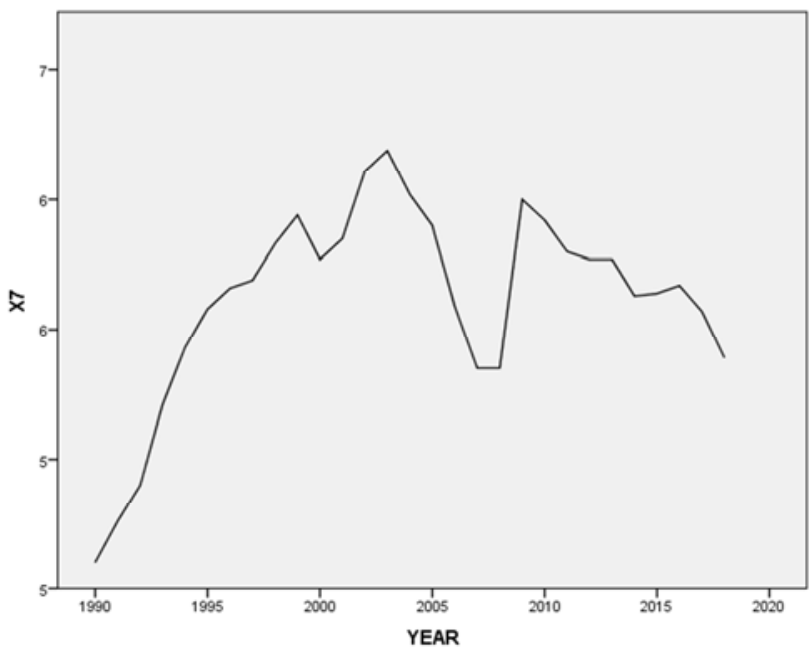

Figure 13. Global unemployment rate, based on data from the World Bank [14].

\section{Conclusion and Recommendations}

If the research finds that $78.1 \%$ of the change in OPEC oil revenues $\mathrm{Y}$ is due to the change in $\mathrm{X} 4$ and $\mathrm{X} 3$, and $21.9 \%$ of the changes are due to other factors that were not taken into account, it is noted that $54.6 \%$ of the change in $\mathrm{Y}$ is due to the change in prices $\mathrm{X} 3$ and $23.5 \%$ of The change in $\mathrm{Y}$ is due to the change in $\mathrm{x} 4$ the contribution of renewable energy to global energy generation. The effect of X3 is positive and it is consistent with the prejudgment of the variable slope signal. There is also a strong positive correlation 0.74 between $\mathrm{Y}$ and $\mathrm{x} 3$. There is also a strong direct correlation 0.602 between $\mathrm{y}$ and $\mathrm{x} 2$. The research also found that the Corona pandemic had clear effects, which were reflected in the image of reducing oil demand as a result of the precautionary measures taken by the countries of the world to confront the Corona pandemic, especially with the prevention of air travel as well as reducing travel by land. To build on it, so the research recommends that:

1. OPEC countries should prepare for the near future by developing flexible strategies and scenarios that take into account sharp oil price fluctuations.

2. OPEC should not fully rely on oil as a source of public revenue and should work to find support factors as a source of income in addition to oil.

3. The necessity to work on activating the role of a management for disease crises and pandemics and to take their consequences into account and follow scientific methods in facing their economic consequences

4. The societal role of international economic organizations, especially in confronting pandemics, became evident as they had an impact on the global economy and caused huge losses to international organizations such as OPEC.

\section{References}

[1] Abd al-Sattar Moussa, 2007, OPEC's share of crude oil production is a tool for price leadership in the international market, Management and Economics Journal, Issue 65, AlMustansiriya University, Iraq, pp. 47, 48.

[2] Anika Labiba Islam \& Ana Espinola - Arredondo2018, Do renewables affect the strategic behavior of OPEC? School of Economic Science, Washington University, Washington State University, pp. 1-4.

[3] Boukasbah and others 2017, The Status of the Organization of Petroleum Exporting Countries (OPEC), in the global oil market, reality and prospects, Faculty of Economic Sciences, University of Martyr Hama Lakhdar in Wadi, Algeria, pp. 36, 95.

[4] Clifford Ogbeide 2008, Opec's Organization Structures, its strategic, aims \& objectives, production, Quota in cohesion within 2008- Msc2540, pp. 5-10.

[5] Ebghaei, Felor, 2007, Opec and its role in regulating price of petroleum, Hacetepe University, department of Economics, Ankara Turkey, MPRA paper No, 8015, posted 13 Jul. 2017, pp. 7-11.

[6] Ehab Ismail, (2013), wind energy policies in thirty years have developed lessons learned from twelve wind energy markets, www.energyandeconomy.com, Egypt New and Renewable Energy Authority.

[7] Geoffrey Heal and Karoline Hallmeyer, 2015, How lower oil prices impact the competitiveness of oil with renewable fuels, Columbia, SIAP, center on global energy policy, PP. 7-12. 
[8] IPCC (2012), Renewable Energy Sources and Climate Change Mitigation, Policy Makers Summary and Technical Summary, Reprinted with corrections in 2012, ISBN 978-92-9169-131-9 IPCC Special Report, p. 9.

[9] Lopez-Corrdova, Ernesto. 2020, Digital Platforms and the Demand for international Tourism Services, World Bank Policy Research Working Paper WPS9147, P7.

[10] Nashwi Mustafa 2014, The Impact of Global Economic Fluctuations on Oil Prices, College of Administration and Economics, King Saud University, p. 1720.

[11] OPEC Official website, https://www.opec.org/opec_web/en

[12] OPEC Bulletin 2020, Monthly oil market report, 1010ViennamAustria, p. 3.

[13] Official OPEC website www.opec.org/opec_web/en/data_graphs/330.htm.

[14] Official World Bank website, https://data.albankaldawli.org/indicator/NY.GDP.PETR.RT.Z S.

[15] U.s Energy information derived from data published in the October 2020, short term energy outlook, Oil \& Gas Journal (ogj.com).

[16] Pinar Deniz, 2019, oil price and renewable energy: oil dependent countries Marmara, university, department of economics, Istanbul, - Turkey, pp. 1-3.

[17] Rabah Arezki, Hangwen, 2020, dealing with a Double Shock: The Coronavirus Pandemic and the Collapse of Oil Prices, World Bank, www.albankaldawly.org Covid 19 and Oil Price
Collapse: Coping with a Dual Shock in the Gulf Cooperation Council Rabah Arezki, Rachel Yuting Fan and Ha Nguyen.

[18] The Arab Center for Research and Policy Studies 2015, The implications of lower oil prices on the economies of the Middle East oil-exporting countries, Al-Dafna, Street 826, Area 66, Qatar, P. O. Box 10277, p. 28, 29.

[19] The Arab Center for Research and Policy Studies 2017, OPEC's dilemma between market share and production limitation, Wadi Al-Banat, Al-Dhayin, Al-Tarfa Street, Area 70, Qatar, P. O. Box 10277, p. 13, p. 19.

[20] Troster, Victor and Shahbaz, Muhammed and Uddinm, Gazi Salah, 2018, Renewable Energy, Oil Prices, and Economic Activity, A Granger-causality in Quintiles analysis, universities de les illes Balears, Spain, Montpellier Business School, France, Linkoping University, Sweden, MPRA. PP. 33.

[21] https://www.statista.com/statistics/262858/change-in-opeccrude-oil-prices-since-1960, Johannes-Brahms-Platz, Statista, GmbH, 20355, Hamburg Germany.

[22] International energy agency, Renewables Information, USA, https://www.iea.org/data-andstatistics.

[23] https://energypost.eu, Energy post, 60 years on, Opec should take control again, cut supply, raise prices to fund its tractions, energy post.

[24] www.cnbc.com/2020/04/01/5-charts-that-explain-the-saudiarabia-russia-oil-price-war-so-far.html, U.s Energy information derived from data published in the April 2020, short term energy outlook, Oil \& Gas Journal (ogj.com). 